\title{
Analysis of Times Indonesia News in UM Jember Student KKN-PM Program
}

\author{
Suyono \\ Communication Studies Program \\ Universitas Muhammadiyah Jember \\ Jember, Indonesia \\ suyono.sulaiman@unmuhjember.ac.id
}

\begin{abstract}
Mass Media is still considered as the most effective public information delivery agency. Especially, the number of Online Media continues to increase in the current 4.0 era. The KKN-PM program (Community Work Program Community Empowerment) conducted by LPPM (Institute for Research and Community Services) Muhammadiyah University of Jember is routinely conducted twice a year, this time is quite interesting to be investigated, because of the many reports related to these activities, through a number of online media, local and national.The focus of this research is only on the TIMES INDONESIA Online Media report which has reported more than $20 \mathrm{KKN}$ activities from various groups. Method The research used is a qualitative content analysis which focuses more research on the contents of explicit or manifest communication. In this case, researchers focus more on the content of news texts published by TIMES INDONESIA online media. Furthermore, the results of this analysis are described using the concept of public relations about media and the establishment of an institution's reputation. The results showed that the ongoing news in the media, could be considered an Public Relations effort in shaping the branding reputation of the University of Muhammadiyah Jember. Considering the TIMES INDONESIA text production tends to display a positive branding reputation for all KKN-PM activities of the University of Muhammadiyah Jember.
\end{abstract}

Keywords-TIMES INDONESIA, Branding Reputation, KKPM UM Jember

\section{INTRODUCTION}

The mass media still has a very big role in spreading information to the community. The media is still a mainstay of government and private institutions, for socialization programs in various fields. One of the most current examples today is the health sector. The government needs the media, to educate people to behave in a healthy life, so that they are free from the covid 19.

As we all know, that the role of the mainstream mass media has begun to fade. Along with advances in information and communication technology, conventional media in the last decade has begun to be abandoned by the public. Media consumers in finding and obtaining information have switched to new media platforms, both in the form of digitalbased mass media or often called online media or media that are directly controlled by the public or commonly called social media.

McQuail, in the Theory of Mass Communication, argues that the mass media are categorized in several groups, namely based on technology, materials and genres [1]. Advances in information and communication technology at this time, has given birth to various new media platforms, internet-based or often called online media.

McQuail further defines new media as an electronic technology device that was born from the advancement of information and communication technology [1]. Therefore, the mem bed will this new media technology is the use of the device. Media This new one is using the transmission system, via cable or via pathways satellite, system computerization, system miniaturization, information storage and retrieval systems, and systems serving images, with a combination of text and graphics.

Because it is supported by technological devices that promise a lot of convenience, this new internet-based media technology is able to develop rapidly. Even his current role has succeeded in taking over the role of conventional media, such as newspapers and magazines, for the print media category. Likewise, with electronic media that were born first, namely radio and television.

Anis Hamidati cite his opinions Rogers, to say there are three main characteristics that mark the presence of new media-based communication technologies and information, namely interactivity, de-massification, and asynchronous. Interactivity is the ability of its communication system i new to talk back to the user. It's like a person who was participating in a conversation private.

The fat other new media are de-massification. This means that this media is mass or involves many participants or the public. Therefore, the control or control of this mass communication system no longer rests on the media manager, like the mainstream media, but is already in the hands of the public or media consumers.

While the third characteristic of new media, namely asynchronous, means that new media has the ability to send and receive messages, in accordance with the desires and wishes of each individual media consumer. In contrast to mainstream media, the delivery of messages (broadcast news) is controlled entirely by the manager or producer of the media [2].

One of the popular new media products is internet-based media or popular with the term online media. With the help of computers and smart phones, a variety of information can be broadcast by managers, and can be accessed easily by people in various parts of the world, quickly and cheaply. Whatever information products, whether in the form of news, education, 
entertainment and simply information about human activities, can be easily conveyed to the public.

McQuail divides new technology-based media into several perspectives [1]. First, the new media in perspective Media Culturalis. That is, new media groups are paying more attention to the content and subjective reception of media messages, especially related to the personal environment. And fokus studies on public media consumers associated with a variety of media choices based culture, genre, or other motives that fokus on individual audiences.

Perspective bothie media materialis the emphasis on structural and technological aspects of the media. Fokus her to the content and all the processes of formation of content leads to the effects of any media used or exposed to the public. Usually, this new media content is widely used by the power of political parties to convey their party policies, in order to influence the grass root mass, in the interests of mass mobilization and other political interests.

Next, the third is the sosio culturalis point of view. This point of view emphasizes the influence of social factors on production, media perception, and media functions in a social life perspective. In this case, the new media utilizes social and cultural issues, as the dominant subject. Usually, media like this are greatly influenced by the large forces that control it. Its role is sometimes far more important than economic and political issues. Naturally, new media often creates new problems, in addition to functioning as a counterweight to information, but also not infrequently the new media actually becomes a means of dividing unity and unity in society.

Perspective fourth said McQuail, is the new media in perspective Socio Materialist, which saw media and its contents as a reflection of material conditions and political economy of the community. In this perspective is the focus of attention is the power of capital ownership and control power media ideology. Therefore, every content production and all types of media must be analyzed more deeply and criticized, because it is very likely related to an ideology based on the strength of capital ownership and power.

Mass media is not always free of value. That is, any information presented by the media, whether in the form of writing, pictures or photos, is not delivered just like that. But it takes a selection and interpretation process, by the ranks of the media editor. The information presented in the media is the work of the editorial team in defining empirical reality that has been captured by the media in the field.

In many discourse analysis theories, reporting in any media certainly has a tendency to be impartial or impartial, every object reported. And this has become a common pattern for the media in producing news. One example, every journalist who does the job of reporting in the field, will make an initial selection of the information he receives. Of the many facts that are spread in the field, of course not all of them will be recorded as information for news material. Besides being limited by the ability of individual journalists, selection is also influenced by subjective influences.

The next selection came from the media editorial team. Not to mention if there is an intervention from the capital owner, the editorial team often cannot refuse, if the capital owner, asks not to write an event that has an interest in the survival of his business or other strategic interests.
Some market -oriented media have various sources of funds that come from investments. Other sources also come from advertisers, consumers, and sometimes also from community subsidies where the funders are sometimes independent and sometimes in favor of certain interests [1].

Naturally, if there is news that reaches the readers, it is not exactly the same as the real reality on the ground. Media involvement in forming the image of an institution or institution actually involves the contestation of interests from various interests. It is in this context that the media are tested to the extent of their professionalism, especially in maintaining the independence of reporting and not being too impartial.

Because it becomes interesting, seeing the fact that the activities of the KKN conducted by the University of Muhammadiyah Jember (UM Jember) in 2020, were covered by many mass media. Besides being widely reported by online media, this time Student UM Jember, also several times was reported by Radar Jember (Jawa Pos Group), one of the influential print media in Jember Regency and its surroundings.

However, the focus of this research was carried out by analyzing the coverage of TIMES INDONESIA online media. Because of this cyber-based media, it has many readers and has a fairly extensive network with many branch offices or journalist representatives scattered in various regions throughout Indonesia. Of course, this media coverage, as long as KKN activities take place, will have a significant influence on the UM Jember institution, especially in building a positive image that has the potential to improve the good name or prestige of the institution in the public eye.

Reputation according to Charles J. Fombrun is not only limited to the views that are built on the public [3]. But reputation also includes various aspects, such as: core values, values, identity, projection, and image. Reputation also involves a picture or representation of the past and the future prospects of an institution or company, which describes the attractiveness of the whole institution for all its main constituents, when comparing with its competitors

Furthermore, Ardianto quoted Fombrun's opinion, explaining that reputation is an intangible asset that is difficult to measure and explain its existence. Because reputation is not a product that can be easily identified and seen in plain sight, because of its abstract form. However the existence of a good reputation in an institution, can strengthen the institution's position when dealing with competitors.

A good reputation will increase the credibility of the institution and make consumers more confident. They, consumers will get what the agency has promised to them. Reputation is a guarantee that consumers, in this case students or prospective student communities, will get something according to their expectations or desires.

Public Relations, according Kriyantono cites the opinion of Jefkins, is a communication system for creating goodwill [4]. Meanwhile, according to Grunig \& Hunt Public Relations is the management of communication between an organization and its public. Therefore, the role of Public Relations is very important for an institution or company, to foster trust and establish cooperation with the community. 
This collaboration is certainly for the sake of smooth running of the institution or company .

Therefore, it states that the Public Relations, Kriyantono carry out management functions of communication, so that the purpose of PR that is the purpose of communication [4]. To achieve the communication goals of an institution or company, one of which can be pursued through collaboration with the media to publicize all the activities of the institution through media coverage.

The definition of publicity, according to Kriyantono is as follows: A information or action that brings a person to public notice. The activity of the company for reporting its own business news. The activities of introducing the company and or its products to the large number of people through mass media [4].

Meanwhile, in the eyes of the mass media, publicity is information that comes from an event, activity, or other activity outside of media interference, but is used by the media as a source of information, because the information is feasible and meets the requirements to be used as news material. This requirement in the media world is often called news value.

People who served as public relations should exploit to the maximum, if there are media who will be covering the institution or organization they represent [4]. By utilizing the media with maximum publicity, the public of the institution or organization shall obtain sufficient information, it is hoped the public can get to know more closely the institution or organization ter call

\section{RESEARCH METHOD}

The method used in this research is qualitative content analysis. According to Kriyantono qualitative content analysis focuses more research on the contents of explicit or manifest communication [4]. In this case, researchers focus more on the content of news texts published by TIMES INDONESIA online media. Furthermore, the results of this analysis are described using the concept of public relations about media and the establishment of an institution's reputation .

Furthermore, Ida (2001) in Kriyantono provides an overview of the stages in qualitative analysis research, which includes: identifying problems, getting to know or being involved with the process and context of information sources, determining samples and selecting dukomen to be unit of analysis, conducting data analysis, and integrating data findings with the interpretations of researchers [4]

In this research, researchers will examine the content of TIMES INDONESIA online media, as many as 22 news, all of which are related to the news of KKN-PM activities carried out by Muhammadiyah University students in Jember. The KKN-PM activities, which were participated by 841 participants and joined in 40 groups, were carried out from 29 January to 27 February 2020. The activity centers were located in four sub-districts namely Jelbuk, Kalisat, Sukowono and Ledokombo, all of which were in Jember Regency.

\section{RESEARCH FINDINGS}

Every college is required to carry out the Tri Dharma, namely carrying out education and teaching, research, and community service. It is also to fulfill the mandate of Law,
Undang-Undang Sistem Pendidikan Nasional No.20/2003. The task of carrying out the Tri Dharma was left to an institution that we often hit LPPM. One of LPPM's work programs is to provide community service that gradually involves all students, through $\mathrm{KKN}$.

For Muhammadiyah Colleges (PTM) throughout Indonesia, this Tri Dharma has long been changed to Chess Dharma, because there is a fourth dharma that PTM has to do, namely Al-Islam and Kemuhammadiyahan. At Muhammadiyah University in Jember, since 2015, the Community Service Program (KKN) has been carried out with a focus on community empowerment. Therefore, the KKN program at UM Jember was changed to KKN-PM, because the focus of its activities was community empowerment.

Jember Muhammadiyah University annually sends its students to KKN, in two waves. The first wave was carried out in January-February, while the second wave was carried out in August-September, with an average number of participants of 750 - 1000 students.

Through this program, students are expected to be able to help the community through various activities, especially helping the economic empowerment of the community, in addition to various other mentoring programs, such as education, health, and other social activities.

As explained by the Head of the Research and Community Service Institute (LPPM) Muhammadiyah University of Jember, Dr. Bagus Rintyarna, MT., that quality of a university academic can not be separated right from the successful implementation of the Tri Dharma or Catur Dharma college. For Muhammadiyah Universities by adding dharma fourth, Al-Islam and Kemuhammadiyahan.

"Universities can not just focus on the education and teaching of course, but also should be concerned and responsive to efforts to contribute to society and the state through the activities of research and also dedication in langsnung to the community ," he said .

It is also in line with the vision LPPM, namely $m$ enjadi right institution enlightenment for research and community service in an honest and trustworthy in the internal and external environment, so as to create an independent and prosperous society that pleases Allah.

The MISSION carried by this institution, said Bagus, there are four main points:

- S sa vehicle for a group of scientists who are creative, skilled, thinkers and pioneers of reform of human civilization towards positive progress.

- Serving as a center for the study and development and maintenance of science and technology.

- Fostering and developing highly dedicated teaching staff and students to jointly advance science through training, research and community service.

- As a forum to improve and develop cooperation networks in the field of research and community service with external institutions.

University of Muhammadiyah Jember as a higher education nstitution in East Java seeks to improve quality in all fields, both academic and non-academic. One of 
them is the field of research and community service. As an institution in charge of managing all research activities and community services, both intra and extra university universities (regional, national, and international).

LPPM UM Jember, said Dr. Bagus, has facilitated all forms of collaborative research and community service activities, both between fields of science and between institutions. LPPM is also a place for the formation of various study centers and centers for activities in UM Jember.

"We also facilitate a variety of training, workshops and debriefing on scientific and service practices. In essence, LPPM UM Jember carry out duties as an institution that is responsible for increasing the quantity and quality of the research community academica UM Jember, the estuary is the product of science and technology-SOSBUD (science, technology, arts, social and cultural) and devoted himself to the people for the glory of the nation and state, " explained Bagus.

As for policy LPPM, said Good, geared to empower research-based Science and Technology (IPTEK) and Iman and Taqwa (IMTAQ). It is hoped that by empowering the community it can elevate people's lives and welfare. This is consistent whit what is written in STATUTA and RENSTRA (Strategic Plan) UM Jember.

The direction of the research policy outlined by the University of Muhammadiyah Jember includes:

- The direction of the research is focused on the multidisciplinary approach to science that is spread across each faculty and study program.

- Research priorities or focus are grouped into several categories of scientific fields, including religion, education, economics, social and politics, psychology, agriculture, engineering and informatics.

- The research policy framework of the University of Muhammadiyah Jember is categorized into two types, namely bottom up research and top down research

\section{Equations KKN from the Media Perspective}

This year's KKN-PM was held on January 29 - February 27, 2020, with 841 students participating. They are divided into 40 groups. The location of KKN-PM this year is centered on four sub-districts in Jember Regency, namely Jelbuk, Kalisat, Sukowono and Ledokombo Districts.

The KKN-PM program implemented by the University of Muhammadiyah Jember, this year, was apparently covered by the media, especially online media. Since this activity was carried out, several local Jember media have reported it, with some angels. They publish interesting student activities. Especially empowerment activities that involve many members of the community.

It so happened that the location chosen for this year's KKN was in an area that was economically still powerless. The economic condition of the population in the northern part of Jember is relatively not prosperous when compared to the population living in the southern part of Jember.

This is understandable, because the geographical conditions of the northern part of Jember, mostly consisting of areas of dry land that are less fertile, so that many residents are used to grow a kind of polowijo and tobacco. Very little land can be used for productive rice fields with technical irrigation.

Therefore, the presence of students through KKN-PM activities, is considered to bring many benefits to the community. Moreover, the KKN activities are also directed to assist community empowerment. Naturally, if a lot of media are interested in reporting every activity held by students with the community.

From the analysis of research conducted by researchers on the content of online media reporting texts, especially TIMES INDONESIA, there are several KKN student activities that attract media journalists to write them into the news. Among them, news relating to the Education Sector were 3 news, Health and Nutrition 7 news, Economic Empowerment 6 news, Social and Culture 5 news, and 1 News environmental Conservation.

The detailed news in the online media TIMES INDONESIA as in the following tables:

TABLE I. THEMES: EDUCATION AND TECHNOLOGY

\begin{tabular}{|l|l|l|l|}
\hline No & Goup & \multicolumn{1}{|c|}{ Place } & \multicolumn{1}{|c|}{ News Tittle } \\
\hline 1 & $\begin{array}{l}\text { KKN- } \\
35\end{array}$ & $\begin{array}{l}\text { Desa Ajung, Kec. } \\
\text { Kalisat }\end{array}$ & $\begin{array}{l}\text { Here's How UM Jember KKN } \\
\text { Students Fill Leisure Time for } \\
\text { Ajung Village Children }\end{array}$ \\
\hline 2 & $\begin{array}{l}\text { KKN- } \\
06\end{array}$ & $\begin{array}{l}\text { Desa Pocangan Kec. } \\
\text { Sukowono }\end{array}$ & $\begin{array}{l}\text { Holds Literacy Program, UM } \\
\text { Jember Students Establish a } \\
\text { Community Reading Park in } \\
\text { Pocangan Village }\end{array}$ \\
\hline 3 & $\begin{array}{l}\text { KKN- } \\
40\end{array}$ & $\begin{array}{l}\text { Degree of Counseling, UM } \\
\text { Kec. Ledokombo Karang Paiton, } \\
\text { Jember Students Introduce the } \\
\text { Impact of Technology to } \\
\text { Karang Paiton Elementary } \\
\text { School Students }\end{array}$ \\
\hline
\end{tabular}

In (Table 1), researchers gathered TIMES INDONESIA news that discussed the role of KKN students, in the fields of education and technology. There are at least three KKN groups scattered in three different districts, namely in the Districts of Kalisat, Sukowono and Ledokombo, which give more attention in the field of public education.

In Ajung, District Kalisat for example, TIMES INDONESIA write a story with the headline: Here's How Students KKN UM Jember Charge Children Son A son Ajung. The news, written in a straight news style, illustrates the activities of students who are trying to make use of the free time of local village children, by helping them learn, both school lessons and studying the Koran, at a local mosque or mosque.

While students who had KKN in the Village of Pocangan, Kec. Sukowono, TIMES INDONESIA revealed a story entitled: Literacy Program Title, UM Jember Students Establish Community Reading Gardens in the Village of Pocangan. The news, written by an IT journalist, illustrates the activities of students who are trying to collect used books and compile them in the form of village libraries, to be used as a learning tool for the village children. This activity is commonly called TBM (Community Reading Park), which is further management, can be carried out by the community together. 
Furthermore, a student KKN group from Karang Paiton Village, Ledokombo Subdistrict, TIMES INDONESIA journalist wrote a story entitled: Extension Title, UM Jember Students Introducing the Impact of Technology to Karang Paiton Elementary School Students. This news tells the story of students who are trying to provide counseling and explanation about the positive and negative impacts of using smart phones. Technology, according to students, is only a tool, so the results or impacts that occur depend on how we utilize the technology. Preferably, technology is used for positive things.

TABLE II. THEMES: NUTRITION AND HEALTH

\begin{tabular}{|c|c|c|c|}
\hline No & Group & Place & News Tittle \\
\hline 1 & $\begin{array}{l}\text { KKN- } \\
01\end{array}$ & $\begin{array}{l}\text { Desa Sukosari, Kec. } \\
\text { Sukowono }\end{array}$ & $\begin{array}{l}\text { Emergency Stunting, UMN } \\
\text { Student Community Service } \\
\text { in Jember is Enthusiastically } \\
\text { Conducting Counseling and } \\
\text { Sharing Nutritious Foods }\end{array}$ \\
\hline 2 & $\begin{array}{l}\text { KKN- } \\
29\end{array}$ & $\begin{array}{l}\text { Desa Slateng, Kec. } \\
\text { Ledokombo }\end{array}$ & $\begin{array}{l}\text { For Stunting Case, Student of } \\
\text { KKN } 29 \text { UM Jember Held } \\
\text { Counseling in Slateng } \\
\text { Village }\end{array}$ \\
\hline 3 & $\begin{array}{l}\mathrm{KKN}- \\
36\end{array}$ & $\begin{array}{l}\text { Desa Kalisat, Kec. } \\
\text { Kalisat }\end{array}$ & $\begin{array}{l}\text { UM Jember KKN students } \\
\text { and STIKES Dr. Soebandi } \\
\text { Collaborate on JJS in Kalisat }\end{array}$ \\
\hline 4 & $\begin{array}{l}\mathrm{KKN}- \\
32\end{array}$ & $\begin{array}{l}\text { Desa Jelbuk, Kec. } \\
\text { Jelbuk }\end{array}$ & $\begin{array}{l}\text { The Stunting Case in Jelbuk } \\
\text { Tinggi Village, Student of } \\
\text { KKN UM Jember Held } \\
\text { Counseling }\end{array}$ \\
\hline 5 & KKN- & $\begin{array}{lr}\text { Desa } & \text { Dawuhan } \\
\text { Mangli, } & \text { Kec. } \\
\text { Sukowono } & \end{array}$ & $\begin{array}{l}\text { Concerned About the Golden } \\
\text { Age of Children, UMN } \\
\text { Student Community Service } \\
\text { of Jember Holds Counseling } \\
\text { to Parents }\end{array}$ \\
\hline 6 & KKN- & $\begin{array}{l}\text { Desa Sumberanget, } \\
\text { Kec. Ledokombo }\end{array}$ & $\begin{array}{l}\text { Students of KKN UM Jember } \\
\text { Hold Health Counseling to } \\
\text { Prevent Transmission of } \\
\text { Hepatitis and Tuberculosis }\end{array}$ \\
\hline 7 & $\begin{array}{l}\mathrm{KKN}- \\
29\end{array}$ & $\begin{array}{l}\text { Desa Slateng, Kec. } \\
\text { Ledokombo }\end{array}$ & $\begin{array}{l}\text { Elementary Students in } \\
\text { Slateng Village Join PHBS } \\
\text { Counseling from UM Jember } \\
\text { Community Service Students }\end{array}$ \\
\hline
\end{tabular}

In (Table 2), the researchers collected TIMES INDONESIA news that discussed the role of KKN students, in providing counseling related to nutrition and public health issues. For this field, there are many activities carried out by students, considering that almost every group has students from the Faculty of Health Sciences (Fikes), who are very knowledgeable about issues related to public health. The study found at least seven news related to this matter.

Because there is too much news about the health sector, researchers will not review all the news that exists. This is related to the limitations of the research page set by the committee. Therefore there are only a few news items that need to be analyzed. For example, news from the KKN-01 group in Sukosari Village, Sukowono District . The activities that were written as news by TIMES INDONESIA were: Emergency Stunting, Student of UM Jember Community Service Program Doing Counseling and Sharing Nutritious Food

This news reviews the participation of students to overcome the stunting problem that is often found in the region. In fact, students consider that this problem has been categorized as an emergency, because cases of stunting or cases of infants who show symptoms or signs of malnutrition, are quite a lot. Therefore, students consider the need to immediately gather community members, especially those who have toddlers (babies under five years old), to be given counseling and direction, how to care for healthy babies, by providing a nutritious food intake, but cheap and easy is obtained.

It turned out that this stunting case also hit many other villages, especially those villages whose social economic level was less fortunate. In the northern part of Jember, most of the villages are inhabited by economically limited population. As also happened in Slateng Village, Kec. Ledokombo, Kalisat Village, Kec. Kalisat, Desa Jelbuk, Kec.Jelbuk, and Dawuhan Mangli Village, Kec.Sukowono. While in Sumberanget Village, Kec. Ledokombo, students are more focused on Health Education to Prevent Transmission of Hepatitis and Tuberculosis, and in Slateng Village, Kec. Ledokombo, counseling aimed at the student primary school (SD) related to a clean and healthy living culture (PHBS).

TABLE III. THEMES: ECONOMIC EMPOWERMENT

\begin{tabular}{|l|l|l|l|}
\hline No & Group & \multicolumn{1}{|c|}{ Place } & \multicolumn{1}{c|}{ News Tittle } \\
\hline 1 & $\begin{array}{l}\text { KKN- } \\
01\end{array}$ & $\begin{array}{l}\text { Desa Sukosari, Kec. } \\
\text { Sukowono }\end{array}$ & $\begin{array}{l}\text { Emergency Stunting, UMN } \\
\text { Student Community Service in } \\
\text { Jember is Enthusiastically } \\
\text { Conducting Counseling and } \\
\text { Sharing Nutritious Foods }\end{array}$ \\
\hline 2 & $\begin{array}{l}\text { KKN- } \\
29\end{array}$ & $\begin{array}{l}\text { Desa Slateng, Kec. } \\
\text { Ledokombo }\end{array}$ & $\begin{array}{l}\text { For Stunting Case, Student of } \\
\text { KKN 29 UM Jember Held } \\
\text { Counseling in Slateng Village }\end{array}$ \\
\hline 3 & $\begin{array}{l}\text { KKN- } \\
32\end{array}$ & $\begin{array}{l}\text { Desa Kalisat, Kec. } \\
\text { Kalisat }\end{array}$ & $\begin{array}{l}\text { UM Jember KKN students and } \\
\text { STIKES Dr. Soebandi } \\
\text { Collaborate on JJS in Kalisat }\end{array}$ \\
\hline 5 & Kelbuk Jelbuk, Kec. & $\begin{array}{l}\text { The Stunting Case in Jelbuk } \\
\text { Tinggi Village, Student of } \\
\text { KKN UM Jember Held } \\
\text { Counseling }\end{array}$ \\
\hline
\end{tabular}

Student Community Service Program of University of Muhammadiyah Jember is also directed to help the community in economic empowerment. As covered in (Table 3), quite a lot of news was written by TIMES INDONESIA media, related to this field of empowerment. At least, there are six news analyzed by researchers, related to this field. For example, Panduman Village, Kec . Jelbuk, students Initiate the Establishment of the Panduman Coffee Business Community .

While in Karang Paiton Village, Ledokombo District, students help people who have difficulty obtaining subsidized fertilizer by training the community to make their own fertilizer by utilizing household waste and livestock manure owned by residents into fertilizer fertilizer. For this reason, TI reporters write news with the title: Difficult to Get Subsidized Fertilizers, UM Jember Students Invite Farmers in Karang Paiton Village to Utilize Compost Fertilizer .

For residents of Sukosari Village, Kec. Sukowono, a student trains village youth to do business online. TI reporters write news: Boosting Products from Iron Craftsmen Villages, 
UM Jember Students Train Youth in Online Business. In the Village of Kalong, district observations Kalisat, students train people to take advantage of the home page to the cultivation of plants through hydroponics system. And a number of other economic empowerment activities, have been carried out by students during KKN.

TABLE IV. THEMES: SOSIO - CULTURE

\begin{tabular}{|c|c|c|c|}
\hline No & Group & Place & News Tittle \\
\hline 1 & $\begin{array}{l}\mathrm{KKN}- \\
03\end{array}$ & $\begin{array}{l}\text { Desa Mojogemi, } \\
\text { Kec. Sukowono }\end{array}$ & $\begin{array}{l}\text { Student of KKN 03 UM Jember } \\
\text { Maker Preventive } \\
\text { Efforts Against Harassment at } \\
\text { SDN 01 Mojogemi }\end{array}$ \\
\hline 2 & $\begin{array}{l}\mathrm{KKN}- \\
03\end{array}$ & $\begin{array}{l}\text { Desa Mojogemi, } \\
\text { Kec. Sukowono }\end{array}$ & $\begin{array}{l}\text { Student of KKN } 03 \text { UM Jember } \\
\text { and Mothers in the Study of } \\
\text { Discussion on Child Parenting }\end{array}$ \\
\hline 3 & $\begin{array}{l}\text { KKN- } \\
29\end{array}$ & $\begin{array}{l}\text { Desa Slateng Kec. } \\
\text { Ledokombo }\end{array}$ & $\begin{array}{l}\text { Students of UM Jember } \\
\text { Community Service Reclaim } \\
\text { Five hamlet boundaries in } \\
\text { Slateng Village }\end{array}$ \\
\hline 4 & $\begin{array}{l}\text { KKN- } \\
01\end{array}$ & $\begin{array}{l}\text { Desa Sukosari, Kec. } \\
\text { Sukowono }\end{array}$ & $\begin{array}{l}\text { Students of UM Jember } \\
\text { Community Service Explain } \\
\text { the Potential of Sukosari } \\
\text { Village in the Musrenbangdes }\end{array}$ \\
\hline 5 & $\begin{array}{l}\mathrm{KKN}- \\
29\end{array}$ & $\begin{array}{l}\text { Desa Slateng, Kec. } \\
\text { Ledokombo }\end{array}$ & $\begin{array}{l}\text { Students of UM Jember KKN } \\
\text { Join Routine Study at Task } \\
\text { Location }\end{array}$ \\
\hline
\end{tabular}

TABLE V. Themes: Environmental Conservation

\begin{tabular}{|l|l|l|c|}
\hline No & Group & \multicolumn{1}{|c|}{ Place } & \multicolumn{1}{|c|}{ News Tittle } \\
\hline 1 & $\begin{array}{l}\text { KKN- } \\
35\end{array}$ & $\begin{array}{l}\text { Desa Ajung, Kec. } \\
\text { Kalisat }\end{array}$ & $\begin{array}{l}\text { UM Jember students and 100 } \\
\text { residents plant 100 Fruit Trees } \\
\text { in Sumber Malang Hamlet }\end{array}$ \\
\hline
\end{tabular}

Whereas in (Table 4) and (Table 5), students' activities are more focused on counseling in the social, cultural and environmental fields. In the socio-cultural sector, for example, by providing counseling to several schools related to the dangers of bullying that befalls school children. Besides other social activities, by inviting the community to be socially active and protecting the environment with a green program.

\section{CONCLUSION}

From the research analysis, the news published by TIMES INDONESIA online media includes news that is positive. Considering the news, it is positively correlated with good reputation regarding the name of the institution, in this case the University of Muhammadiyah Jember in the eyes of the public and all its relations.
Of course, the role of the media in reporting the agency's activities does not necessarily come just like that. The LPPM, assisted by UM Jember Public Relations officers, has long had positive communication with a number of local and national media. The goal is to build a synergistic relationship that benefits both parties.

Therefore, in the future good collaboration must continue to be improved in quality and quantity. Because, the mass media according to its function can act as a means of promotion of the management of institutions or companies, both related to new products and / or the services they manage. The mass media can also play a role as a partner in influencing public opinion regarding agency policies or programs .

The mass media also becomes an effective means for strengthening corporate image or branding institutions, to support the development institutional performance. Conversely, media can also be a nuisance or damage, the image of the institution, with news that has a negative perspective or preaches the weaknesses of the institution.

Of course this really depends on how he institution's policies, collaborations and use the media for positive goals. This is where the role of public relations, as a sub-unit or element that is usually inherent in an institution, to communicate with the outside world or with other stakeholders, to enhance the image or reputation of the institution in the public eye.

The results of this study indicate that the ongoing reporting in the media, can be considered as Public Relations efforts in shaping the branding reputation of the University of Muhammadiyah Jember. Because the TIMES INDONESIA text production tends to display a positive branding reputation for all KKN-PM activities of the University of Muhammadiyah Jember.

\section{REFERENCES}

[1] Mc Quail, Denis. Communication Theory. Issue 6, Book 1. Jakarta. Salemba Humanika. 2011

[2] Hamidati, Anis. Communication 2.0 Theoritization and Implications. Yogyakarta. Eye Rice Pressindo. 2011.

[3] Ardianto, Elvinaro. Research Methodology and Public Relations Qualitative. Bandung. Symbiosis. 2016.

[4] Kriyantono, Rachmat. Practical Communications Reasearch Techniques. Jakarta. Kencana Prenada Media Grup. 2008. 